\title{
The Sexuality Project (Pro-Sex) of the Institute of Psychiatry of the HCFMUSP: first year of activities
}

\begin{abstract}
The results of one year of activities of a multidisciplinary staff comprised of five psychiatrists, one urologist, one gynecologist, and seven psychologists, who integrate the Sexuality Project (PRO-SEX) of the Institute of Psychiatric, Hospital das Clínicas, College of Medicine, University of São Paulo (FMUSP), are presented. Different sexual disorders were evaluated and treated in 140 patients (116 men and 24 women). In addition, a standard protocol was established for the medical assistance of patients; four research projects have been initiated; and courses were offered to residents in psychiatry, urology, and obstetrics-gynecology, as well as to undergraduate and postgraduate students of FMUSP. The PRO-SEX staff presented their research at one congress and two symposiums, and published four articles. Furthermore, an extensive program was established for 1995 in order to continue the advanced medical study of human sexuality.
\end{abstract}

UNITERMS: Sexuality. Sexual disorders. Multidisciplinary assistance. Medical education. Medical research.

\section{INTRODUCTION}

$\mathrm{T}$ he Sexuality Project (PRO-SEX) is a multidisciplinary project developed to establish priorities in the treatment of sexual disorders, and attend to the needs for assistance, education and research in this area. This approach was proposed because human sexuality and its disorders, cannot be properly studied within a single medical specialty.

The staff of PRO-SEX is comprised of psychiatrists, psychotherapists (physicians and psychologists), urologists, gynecologists and administrative assistants. It began its activities in November 1993.

\author{
Adress for correspondence: \\ Carmita Helena Najjar Abdo \\ Rua Pascal, 181, apto. 41, Campo Belo \\ São Paulo/SP - Brasil - CEP 04616-001
}

From November 1993 through November 1994, 176 patients, 142 men and 34 women, were admitted to our service. Medical assistance was initiated by a performing psychiatric examination, followed by an urological or gynecological examination, according to the sex of patient. Patients were only treated if a sexuality disorder was diagnosed according to the International Classification of Diseases, $10^{\text {th }}$ edition.'

Patients received clinical support (psychiatric, urological, and gynecological) if sexual disorders were due to organic causes. Brief psychotherapy, individual or in group, was used whenever disorders were psychogenically associated or not associated to organic disturbances. Figures 1 and 2 illustrate some characteristics of patients admitted to this study.

On a weekly basis, the medical staff sponsored meetings to present research projects in progress and seminars on important issues; to discuss clinical cases; to establish plans for expanding educational, scientific and assistance activities; and to review the main objectives of this project. 


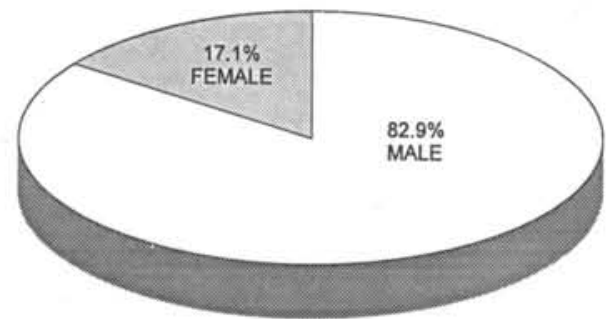

Figure 1 - Gender of Patients Admitted to Pro-Sex (Nov. 93/ Nov. 94)

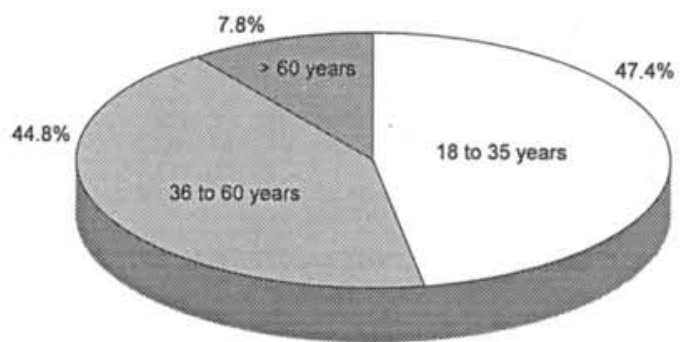

Figure 2a - Proportion of Male Patients Admitted to Pro-Sex, According to Age And Age Group (Nov. 93/ Nov. 94).

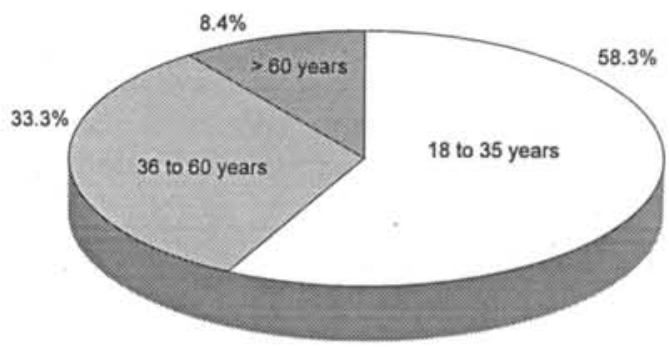

Figure 2b - Proportion of Female Patients Admitted to Pro-Sex, According to Age And Age Group (Nov. 93/ Nov. 94).

\section{Assistance}

Initially, patients of both sexes are submitted to triage and examined by a psychiatrist; men are then evaluated by a urologist and women by a gynecologist.

Once patients are admitted to PRO-SEX, they are submitted to a psychiatric evaluation and to the following specific anamnesis:

\section{MASCULINE SEXUALITY}

Upbringing: education, perception and/or experience of sexuality at home, with friends or relatives.

Secondary sexual development: andropause and incidents (specific diseases and sexually transmitted diseases).

Sexual initiation: masturbation, childhood sexual play, first relationships, first experiences (fantasies, frequency and preferences).

Sexual identity: (approval or disapproval of their biological sex).

Sexual orientation: the opposite sex, the same sex, objects, masturbation (type). 
Importance of sexual activity (in the beginning, currently).

Partners: number, civil status, race, profession, physical appearance, sex, age.

Sexual intercourse: performance during lifetime (in the beginning, evolution and current status)

Frequency of sexual intercourse and favorite caresses

Use of stimulating drugs to facilitate performance.

Emotional life related to sex: need for an emotional relationship, and its interference in sexual pleasure.

Current status of the emotional-sexual life: the presence or absence of a steady partner; number of partners; frequency of sexual intercourse; incidents during sexual intercourse (reported spontaneously or prompted).

Importance of values: (cultural, religious, family, related to children, related to the masculine role) and their interference on sexual performance and sexuality.

\section{FEMININE SEXUALITY}

Upbringing: education, perception and/or experience of sexuality at home, with friends or relatives.

Menarche, menopause and pregnancies: number of pregnancies and their acceptance.

Abortions: spontaneous, or induced.

Sexual initiation: masturbation, childhood sexual play, first relationships, first experiences (fantasies, frequency and preferences).

Sexual identity: (approval or disapproval of the biological sex).

Sexual orientation: the opposite sex, the same sex, objects, masturbation (types).

Importance of sexual activity: (in the beginning, currently).

Partners: number, civil status, race, profession, physical appearance, sex.

Sexual intercourse performance: throughout life (in the beginning, evolution and current status); incidents: pain, bleeding, etc.

Frequency: of sexual intercourse and favorite caresses

Emotional life related to sex: need for a relationship, and its interference in sexual pleasure.

Use of stimulating drugs: to facilitate performance.

Current status of the emotional-sexual life: Presence or absence of a steady partner; number of partners; frequency of sexual intercourse; incidents during sexual intercourse (reported spontaneously or prompted).
Importance of values: (cultural, religious, family, related to children, related to feminine behavior) and their interference on sexual performance and sexuality.

Once patients are thus evaluated and properly diagnosed, they receive specific treatment, i.e., clinical (psychiatric and/or urological or gynecological) or psychodynamic, or both.

Clinical treatment of the underlying mental disorder is based on psychiatric assistance (if the primary disturbance is prior to the sexual disorder). If necessary, psychotherapy is used for a brief period, and focuses on the current sexual disorder. Groups of "limited thematic therapy" are organized - i.e., groups which will approach a specific subject based on patient diagnosis (e.g.. premature ejaculation) - for 12-16 weeks. Thus, these groups are comprised of patients with the same sexual disorder.

Individual psychotherapy, along different lines, is recommended whenever the psychic structure of the patient is such that psychotherapy in group should not be used.

The diagnosis of concomitant etiologies determines multidisciplinary assistance.

\section{RESEARCH}

PRO-SEX has developed the following research projects:

- $\quad$ "Limited thematic therapy for male patients with sexual disorders" (working title). Stage: analysis of data. Authors: Alexandre Saadeh, Filipe Jorge D.T.S. Ferreira, Carmita H.N. Abdo

- "Efficacy of pharmacologic treatment of anxiety in the treatment of premature ejaculation" (working title). Authors: Celso Gromatzky, Carmita H.N. Abdo, Sérgio Ricardo C. de Oliveira.

- "Sexuality and Cardiopathy" (working title). This project is being developed in collaboration with Instituto do Coração (INCOR), with the objective of evaluating the sexual performance of patients with coronary artery disease. Authors: Antonio Mansur, Carmita H.N. Abdo, Alexandre Saadeh.

\section{PRO-SEX published the following articles in 1994}

- Oliveira SRC, Abdo CHN. "Algumas reflexões sobre a importância do casal na gênese de patologia sexuais". "Some reflections on the importance of 
couples in the genesis of sexual disorders." Rev Psiquiat Clín 1994;21(1):15-8. ${ }^{2}$

- Abdo CHN, Gromatzky C, Oliveira SRC. "Concomitância de Depressão, Disfunção Erétil Peniana e Hipotestosteronemia: Relato de três casos". "Concomitance of depression, erectile dysfunction, and hypotestosteronemia: report of three cases." Congresso Brasileiro de Psquiatria. Pousada do Rio Quente, Anais, 1994. ${ }^{3}$

- Abdo CHN. "A mulher no contexto sócio-psíquico: Sexo e Dominação"/"Women in a socialpsychological perspective: sex and domination" (Round Table Topic). XIII Congresso Brasileiro de Psiquiatria. Pousada do Rio Quente, Anais, 1994. ${ }^{4}$

\section{Postgraduation}

In 1994, a comparative study of anxiety disorders and premature ejaculation was started and is currently being carried out by Sérgio Ricardo Campanella de Oliveira under the supervision of Prof Dr. Carmite H.N. Aldo, for a Masters degree.

\section{Education}

In 1994, PRO-SEX was responsible for the following educational activities for:

\section{Postgraduate students}

- Course: "Aspectos da Sexualidade Humana"/ "Aspects of Human Sexuality" (MPS-726). Responsibility: Prof. Dr. Carmita H.N. Abdo from the Department of Psychiatry, College of Medicine, University of São Paulo.

- Course: "Psicoterapia Familiar"/ "Family Psychotherapy" (MPS-726). Responsibility: Prof. Dr. Carmita H.N. Abdo from the Department of Psychiatry, College of Medicine, University of São Paulo.

\section{Medical residents}

- Course: "Distúrbios Sexuais"/ "Sexual Disorders," for first-year residents of the Department of Psychiatry, FMUSP. Responsibility: Prof. Dr. Carmita H.N. Abdo.

- Lecture: "Aspectos Psíquicos da Disfunção Erétil"/ "Psychical Aspects Of Erectile Dysfunction," for first-, second-, and third-year residents of the Department of Urology, FMUSP.
- Lecture: "Sexualidade Feminina"/ "Female Sexuality," for first-, second-, and third-year residents of the Department of Gynecology and Obstetrics, FMUSP

- Optional training for third-year psychiatry residents of the Department of Psychiatry, FMUSP. Trainees: Filipe D.T.S. Ferreira, Fábio Salzano e Miriam Regina Moretti.

\section{Undergraduate students}

- Lecture: "Aspectos psicológicos do desenvolvimento da Sexualidade"/ "Psychological aspects of sexual development" for the Course of Medical Psychology for the third-year students of FMUSP. Lecturer: Prof. Dr. Carmita H.N.Abdo.

- Lecture: "A família como mantenedora da doença"/ "The family as a maintainer of disease" for the Course of Medical Psychology for third-year students of FMUSP. Lecturer: Prof. Dr. Carmita H.N.Abdo.

\section{INTERNSHIPS}

- For physicians: Dr. Celso Gromatzky, urologist, and Dr. Joserita Serrano de Assis, gynecologist, are responsible for the clinical assistance of patients in the PRO-SEX. They take part in weekly clinical meetings, and participate in research of a multidisciplinary approach.

- For psychologists: Andrea Newmann, Alina D.D. Barone, Aurea R. Giaquinto, Beatriz Kalman, Cecília Brasiliense Carneiro, Ymara L.C. Victolo, Marco Antonio P. Amato, Rita Di Giacomo Domingues collaborate in psychotherapeutic assistance, and take part in clinical meetings and research projects.

\section{PARTICIPATION IN SYMPOSIUMS AND CONGRESSES}

- Symposium of the Interassistance Section of the Institute of Psychiatry, HCFMUSP: "Psiquiatria e Psicologia no Hospital Geral: integrando as especialidades - Sexualidade"/ "Psychiatry and Psychology in a General Hospital: integrating specialties - Sexuality", held in April 1994. 
TABLE 1

Distribution of Patients Admitted to PRO-SEX, According to Civil Status (Nov. 93/ Nov. 94)

\begin{tabular}{lccccc}
\hline \multicolumn{5}{c}{ Civil Status } \\
\hline Men & SINGLE & MARRIED & WIDOWED & DIVORCED & TOTAL \\
Women & $54(46.6 \%)$ & $49(42.2 \%)$ & $4(3.4 \%)$ & $9(7.8 \%)$ & $116(100.0 \%)$ \\
\hline & $9(37.4 \%)$ & $13(54.2 \%)$ & $1(4.2 \%)$ & $1(4.2 \%)$ & $24(100.0 \%)$ \\
\hline
\end{tabular}

- Symposium of the Interassistance Section of the Institute of Psychiatry, HCFMUSP: "Psiquiatria e Psicologia no Hospital Geral: Mulher" / "Psychiatry and Psychology in a General Hospital: Women," held in October 1994.

- XIII CONGRESSO BRASILEIRO DE PSIQUIATRIA held in September 1994: the participation of the professionals of PRO-SEX was previously mentioned under the heading RESEARCH.

\section{DEMOGRAPHIC DATA AND DIAGNOSES OF PATIENTS ADMITTED TO PRO-SEX, DURING THE FIRST YEAR OF ACTIVITIES}

The patients assisted by the clinical staff of PROSEX were evaluated in open interviews by psychiatrists, gynecologists, and urologists. The patients suspected of primary sexual disorders were examined by a urologist (male patients) or a gynecologist (female patients) to exclude the possibility of pathologies of this type.

The psychiatric diagnosis for each patient was recorded in their medical files, and standardized according to the International Classification of Diseases, 10th edition, ICD 10 (1993). Demographic data were obtained by consulting IPQ files.

\section{DEMOGRAPHIC DATA}

\section{GENDER}

One hundred forty patients were selected from a total of 176 cases assisted during the period of this study: 116 were male ( 82.9 percent), and 24 were female (17.1 percent), as depicted in Figure 1.

\section{AGE}

Patients were categorized into three distinct groups based on age, regardless of sex: 18 to 35,36 to 60 , and older than 60 years. The men's ages ranged from 18 to 76 years, and the women's from 19 to 67 . The distribution of patients according to age is shown in Figure 2a and 2b.

The mean age of men ( 37.8 years) is higher than of women (35.2 years). Most of the patients were between 18 and 35 years (47.4 percent male and 58.3 percent female). The younger groups sought medical assistance more often ( 18 to 35 , and 36 to 60 years), corresponding to 92.2 percent of male and 91.6 percent of female cases.

\section{ORIGIN}

All patients admitted came from the city of São Paulo.

\section{CIVIL STATUS}

As shown in Table 1, most of the female patients were married ( 54.2 percent); single women accounted for 37.4 percent of the cases. On the other hand, most of the male patients were single ( 46.6 percent), and married men accounted for 42.2 percent.

\section{DIAGNOSIS SURVEY BY (ICD-10)}

\section{GENERAL CONSIDERATIONS}

As shown in Table 2, from a total of 140 patients with 4.3 percent ( 6 cases) not being properly classified, 2.9 percent ( 4 male cases) had a sexual disorder of organic origin.

One hundred thirty patients had psychiatric diagnoses ( 92.9 percent of total cases): 107 were male ( 82.3 percent) and 23 were female ( 17.7 percent). For comparing data, analyses of different diagnoses were performed for each sex. 
TABLE 2

Frequency of Male Patients without Psychiatric Diagnosis Based on Icd-10 (Nov. 93/Nov. 94) Erectile Dysfunction of Organic Origin

\begin{tabular}{lcc}
\hline Diagnosis & ICD-10 & Number of Cases \\
\hline Diabetes Mellitus with Peripherical Circulatory Disorder & $2506 / 2$ & 2 \\
Atherosclerosis Limbs Ateries & $4402 / 4$ & 2 \\
Total & & 4 \\
\hline
\end{tabular}

This survey also revealed that 32 patients (24.6 percent) showed more than one psychiatric diagnosis; mainly erectile dysfunction and premature ejaculation in 10 cases (31.3 percent of the diagnostic associations and 7.7 percent of total diagnoses).

Other associations will be shown separately for masculine and feminine disorders.

Three patients (two men and one woman) (2.3 percent of the total cases) were homosexual. However, only the female case could be classified by the adopted diagnostic criterion, due to the ego-dystonic character of her sexual orientation (F66.1).

\section{DIAGNOSTIC DATA FOR MALE PATIENTS}

According to the data shown in Table 3, the most frequent diagnosis is premature ejaculation ( 47 cases, 36.7 percent of total cases and 43.9 percent of male cases), followed by erectile dysfunction ( 44 cases, 34.0 percent of total cases and 41.1 percent of male cases).

TABLE 3

Frequency of Diagnoses Among Male Patients

\begin{tabular}{|c|c|c|c|}
\hline Diagnosis & ICD-10 (ref) & Number & Percentage \\
\hline Premature Ejaculation & F52-4 & 47 & $43.9 \%$ \\
\hline Erectile Dysfunction & $\mathrm{F} 52-2$ & 44 & $44.1 \%$ \\
\hline Lack of Pleasure & F52.1.1 & 2 & $1.9 \%$ \\
\hline Transsexualism & F64.0 & 2 & $1.9 \%$ \\
\hline Other Disorder Of Sexual Preference & F65.8 & 3 & $2.8 \%$ \\
\hline Psych. Behav. Dis. Assoc. Sex. Dev. Orient ${ }^{* \star \star \star}$ & F66 $6^{\star \star \star}$ & 2 & $1.9 \%$ \\
\hline Personality Disorder** & $\mathrm{F} 60^{* * *}$ & 3 & $2.8 \%$ \\
\hline Episodes of Depression ${ }^{\star \star}$ & $\mathrm{F} 32^{\star \star \star \star}$ & 2 & $1.9 \%$ \\
\hline Nonspecified Episodes of Anxiety** & F41.9 & 5 & $4.7 \%$ \\
\hline Tranquilizer Abuse* & F13.1 & 1 & $0.9 \%$ \\
\hline Mild Oligophrenia* & F70.8 & 1 & $0.9 \%$ \\
\hline Residual Schizophrenia* & F20.5 & 1 & $0.9 \%$ \\
\hline Bipolar Disorder* & F31.7 & 1 & $0.9 \%$ \\
\hline Social Phobia* & $\mathrm{F} 40.1$ & 1 & $0.9 \%$ \\
\hline Generalized Anxiety Disorder* & F41.1 & 1 & $0.9 \%$ \\
\hline Total & & $\# 116$ & $107.3 \%$ \\
\hline
\end{tabular}

*No Associated Sexual Dlagnoses

"Secondary Diagnosis of Sexual Dysfunction

**Specific Diagnosis Only for the Group

*...Psychic Disorder And Abnormal Behavior Associated with Sexual Development and Orientation

\# Some Patients Presented more than One Psychiatric Diagnosis 
TABLE 4

Frequency of Diagnoses Among Female Patients

\begin{tabular}{lccc}
\hline Diagnosis & ICD-10 (ref) & Number & Percentage \\
\hline Orgasmic Dysfunction & F52.3 & 17 & $73.9 \%$ \\
Lack of Pleasure & 0 & 2 & $8.7 \%$ \\
Dyspareunia & F52.6 & 2 & $8.7 \%$ \\
Ego-Dyst. Homos. ${ }^{* \star}$ & $\mathrm{F} 66.1$ & 1 & $4.3 \%$ \\
Vaginismus & $\mathrm{F} 52.5$ & 1 & $4.3 \%$ \\
Nonspecified Disord. Person. ${ }^{* \star *}$ & $\mathrm{~F} 60.9^{\star}$ & 1 & $4.3 \%$ \\
Total & & $24^{\star \star}$ & $104.2 \%$ \\
\hline
\end{tabular}

- No Associated Sexual Diagnoses

* One Patient has Two Psychiatric Diagnosis

... Ego-Dystonic Homosexualism

.... Nonspecified Personality Disorder

These two disorders account for 85.0 percent of diagnoses in male patients.

The most frequent psychic disorders associated with male sexual dysfunction are: personality disorders ( 3 cases, 2.8 percent male cases); episodes of depression ( 2 cases, 1.9 percent male cases) and episodes of anxiety ( 5 cases, 4.7 percent male cases).

Among the men, 5.7 percent ( 6 cases) did not present any diagnosis related to a sexuality disorder. There were only secondary complaints related to their primary disorders, and thus could not be classified in the group of sexual disorders ( 1 case for each disorder). These disorders were: social phobia (F40.1), tranquilizer abuse (F13.1), mild oligophrenia (F70.8), residual schizophrenia (F20.5), bipolar disorder (F31.7), and generalized anxiety disorder (F41.1).

Two cases (1.9 percent male patients) of transsexualism, 3 cases ( 2.8 percent) of sexual preference disorders (the well-known paraphilia), and two cases (1.9 percent) of psychological disorder and abnormal behavior associated with sexual development and orientation (F66) were also observed.

Thus, most male patients ( 86.7 percent) presented diagnoses of the group F50-F59 (Behavioral syndromes associated with physiological disturbances and physical factors), and only 7.4 percent cases presented diagnoses of the group F60-F69 personality (Personality and behavior disorders in adults). The others (5.6 percent) did not present any sexual disorder.

\section{DIAGNOSTIC DATA FOR FEMALE PATIENTS}

In regard to the female sex, according to Table 4, the most frequent disorder was orgasmic dysfunction
(73.9 percent female patients); two cases ( 8.7 percent) of anorgasmy, 2 cases (8.7 percent) of dyspareunia, 1 case ( 4.3 percent) of vaginismus, and 1 case $(4.3$ percent) of ego-dystonic homosexuality were also observed. There was also one case ( 4.3 percent) of orgasmic dysfunction associated with dyspareunia, and 1 case that could not be classified as a sexual disorder (F60.9 - nonspecified personality disorders).

Among all female patients, 4 cases (17.4 percent) presented a psychiatric diagnosis associated with an identified sexual disorder, and all of these patients presented anxiety disorders ( 3 cases of generalized anxiety disorder, and 1 case of nonspecified anxiety).

No cases of paraphilia were observed, confirming the results of literature about their absolute predominance in men.

Most of the female patients (95.6 percent) were classified in the group F50-F59, and only 4.4 percent in the group F60-F69. Similarly to the male population, these findings demonstrate the prevalence of sexual dysfunctions associated with sexuality disorders.

\section{EXPANSION OF PRO-SEX IN 1995}

The 1st Symposium on Sexuality, "Diagnosis and treatment of sexual disorders," is in its final stage of organization, and will be directed at professionals in the mental health area.

This event will be held at the Institute of Psychiatry of HCFMUSP in October 1995. 
The Educational Clinic of Sexual Disorders, was started in February 1995, and is held weekly, mainly for second-year psychiatry residents of the Institute of Psychiatry of HCFMUSP.

The following are in the planning and organizational stage: the Clinic of Sexuality in Pregnancy (to be established with the Obstetrics Course of the HCFMUSP); the Clinic of Sexuality in Menopause (with the Gynecology Course of the HCFMUSP); and the Clinic of Sexuality in physically-rehabilitated persons (with the Rehabilitation Hospital of HCFMUSP).
Two new projects will be initiated by PRO-SEX for Master's degrees in 1995:

- "Female orgasmic dysfunction: normal variation of sexuality, autonomous nosological symptom or entity,” by Fábio Schimidt Goffi Jr.

- "Limited group psychotherapy for treatment of erectile dysfunction," by Filipe Jorge Dontel Teixeira Soares Ferreira.

The Sexuality Project will be restructured in 1995, and will have three areas: assistance, education and research. Thus, PRO-SEX intends to take a new step in the advanced study of human sexuality, from a clinical point of view.

\section{Resumo}

Os autores apresentam o resultado de um ano de atividade de cinco psiquiatras, um urologista, uma ginecologista e sete psicólogos que fazem parte do Projeto Sexualidade (PRO-SEX) do Instituto de Psiquiatria do Hospital das Clinicas da Faculdade de Medicina da Universidade de São Paulo (FMUSP). Neste periodo, 140 pacientes (116 homens e 24 mulheres) iniciaram tratamento multidisciplinar para transtornos sexuais diversos. Neste período, também, foi estabelecido um protocolo de atendimento, ministrados cursos para médicos residentes de Psiquiatria, Urologia e Obstetricia, bem como para alunos da graduação e da pós-graduação da FMUSP e foram iniciados quatro projetos de pesquisa. Os integrantes do PRO-SEX se apresentam em um Congresso e dois Simpósios e obtiveram quatro publicaçōes. Além disto definiram ampla programaçāo para 1995, no intuito de dar sequeência ao estudo médico avançado da Sexualidade Humana.

\section{REFERENCES}

1. World Health Organization. Classificação de Transtornos Mentais e de Comportamento da Classificação Internacional das Doenças, $10^{a}$ edição (ICD-10). Porto Alegre: Artes Médicas, 1993.

2. Oliveira, SRC, Abdo CHN. Algumas reflexões sobre a importância do casal na gênese de patologia. Rev Psiquiat Clín 1994;21(1):15-8.
3. Abdo CHN, Gromatzky, C, Oliveira SRC. Concomitância de depressão, disfunção erétil peniana e hipotestosteronemia: relato de três casos. XIII Congresso Brasileiro de Psiquiatria. Pousada do Rio Quente, 1994. Anais, Goiás (resumo).

4. Abdo CHN. A mulher no contexto sócio-psíquico: sexo e dominação (tema de Mesa Redonda). XIII Congresso Brasileiro de Psiquiatria. Pousada do Rio Quente, 1994. Anais (resumo). 